\title{
Investigating the coupling between small pelagic fish and marine top predators using data collected from ecosystem-based surveys
}

\author{
G. Certain ${ }^{1,5, *}$, J. Masse ${ }^{2}$, O. Van Canneyt ${ }^{3}$, P. Petitgas ${ }^{2}$, G. Doremus ${ }^{3}$, \\ M. B. Santos ${ }^{4}$, V. Ridoux ${ }^{3}$ \\ ${ }^{1}$ Norwegian Institute for Nature Research-NINA, 7485 Trondheim, Norway \\ ${ }^{2}$ IFREMER, Rue de l'Île d'Yeu, BP 21105, 44311 Nantes Cedex 3, France \\ ${ }^{3}$ Centre de Recherche sur les Mammifères Marins, 5 allée de l'Océan, 17000 La Rochelle, France \\ ${ }^{4}$ Instituto Español de Oceanografía, Centro Oceanográfico de Vigo, Apdo. 1552, 36200 Vigo, Spain \\ ${ }^{5}$ Present address: Institute of Marine Research, PO Box 6404, 9294 Tromsø, Norway
}

\begin{abstract}
The present study is a general multivariate analysis of the spatial association between small pelagic fishes and their predators (seabirds, marine mammals and fisheries), using $6 \mathrm{yr}$ $(18000 \mathrm{~km})$ of transects surveyed in spring in the Bay of Biscay, France. We describe 4 groups of prey-predator association, with explicit distinction of prey size: (1) terns and anchovies (10 to $15 \mathrm{~cm}$ ), (2) common dolphins, common murres, sprat and sardine $(<20 \mathrm{~cm})$, (3) gannets, horse mackerel and mackerel $(15$ to $25 \mathrm{~cm})$ and (4) bottlenose dolphin, horse mackerel and mackerel $(25$ to $40 \mathrm{~cm})$. Our analysis also illustrates the great variability in these associations, with years of strong prey-predator associations followed by years of weak relationships. The analysis allows us to formulate predictions about the structure of the upper-pelagic food web in the Bay of Biscay in spring, and constitutes a good starting point for the analysis of data collected during ecosystem-based surveys in the Bay of Biscay.
\end{abstract}

KEY WORDS: Marine top predators - Small pelagic fishes - Spatial associations - Temporal variability $\cdot$ Pelagic ecosystem $\cdot$ Bay of Biscay

\section{INTRODUCTION}

Energy in marine ecosystems flows through complex food webs, the organisation of which varies in space and time (Cury et al. 2008). When dramatic changes occur in a food web, the complete ecosystem functioning can shift from one steady state to another less stable state. These sudden 'regime shifts' (deYoung et al. 2008) are typical of marine systems, and are often driven by changes at the intermediate trophic level (e.g. small pelagic fishes). Small pelagic fish populations are viewed as a key component in many cases, able to exert a top-down control on zooplankton as well as a bottom-up control on top predators (termed wasp-waist ecosystem structure; Bakun 1996, Cury et al. 2000). Furthermore, they are subject to strong nonlinear 'boom-bust' dynamics (Bakun 2006).

Marine top predators (e.g. seabirds and cetaceans) feed mainly either on large zooplanktonic crustaceans or small pelagic fishes (Pauly et al. 1998, Hunt et al. 2005), which are populations subject to important, non-linear dynamics as suggested by the theory of wasp-waist ecosystems. Marine top predators have high metabolic rates, requiring frequent and substantial intake of prey. Lack of suitable prey can have negative effects on reproductive output and condition in some populations of top predators (e.g. Gremillet et al. 2008), with extreme cases leading to starvation and 
death (Ellis \& Gabrielsen 2001). However, small pelagic fishes are mobile, clustered and unpredictable prey (Haugland \& Misund 2004, Weimerskirch 2007). To cope with the high uncertainty associated with prey distribution and abundance, marine top predators have developed complex foraging strategies, based on optimal foraging paths in a heterogeneous environment (Russell et al. 1992, Viswanathan et al. 1996, Fauchald 1999, Pinaud \& Weimerskirch 2005, Benhamou 2007), combined with an extensive use of socially shared information and cues (Davoren et al. 2003, Silverman et al. 2004).

Top predator populations may also have an important role in marine ecosystems and examples exist of their perceived pivotal role. Sissenwine et al. (1984) hypothesised that the final collapse of the Georges Bank herring population was due to the presence of fin whales Balaenoptera physalus on the spawning grounds used by the remaining herring, after the stock had been seriously depleted by overfishing. Kenney et al. (1997) estimated that the total amount of fish and squid consumed by marine mammals exceeded fisheries catch in the USA Northeast Continental Shelf ecosystem. Although marine top predators are supposed to be primarily controlled by bottom-up processes, their selective removal in chronically overfished systems can also affect the stability of ecological communities (Bascompte et al. 2005, Myers et al. 2007). In fact, the relative importance of bottom-up versus top-down regulation in open-sea ecosystems is probably a matter of scale, with bottom-up processes evident at large spatial scale, and top-down processes becoming more important at smaller spatial scales (Hunt \& McKinnel 2006). Many species of marine top predators (e.g. cetaceans, sharks) are protected by legislation and international agreements which aim to minimise adverse anthropogenic impacts on their populations (Lewison et al. 2004). Improved knowledge of the factors that can affect their population dynamics is vital to guarantee the success of protection and conservation actions.

Survival and abundance of top predator populations, although primarily controlled by the availability of their main prey (e.g. Wanless et al. 2007), are also likely to be influenced by interactions with other predators and fisheries. For example, seabirds may benefit from the dolphin's hunt (e.g. Clua \& Grosvalet 2001), use other species as social cues to locate prey (Silverman et al. 2004), kleptoparasitise other species (e.g. Garthe \& Hüppop 1998) or scavenge fisheries discards (e.g. Votier et al. 2004, 2008, Gremillet et al. 2008). Some species with reduced competition efficiency (e.g. kittiwakes Rissa tridactyla) need to locate food quickly, before more aggressive species that mostly rely on scrounging and scavenging exclude them from the food patch (e.g. large gulls Larus spp.; Camphuysen et al. 2006). Ubiquitous species (e.g. northern gannets Morus bassanus) may be able to use both feeding strategies (Garthe \& Hüppop 1998). A predator species may contribute to the foraging of several others because it drives prey toward the sea surface or because it acts as a major information cue to locate suitable feeding grounds (e.g. killer whales: Ridoux 1987; black-browed albatrosses: Silverman et al. 2004; tuna: Weimerskirch et al. 2005).

Therefore, achieving a good understanding of the 'vertical' relationships that exist between the marine prey and predator communities, as well as of 'horizontal' relationships within each of these 2 communities, is a great step towards an integrated understanding of the functioning of pelagic ecosystems. Such work is needed to achieve the objectives of ecosystem-based management (Pikitch et al. 2004), by offering ways to better understand and predict the behaviour of marine systems and by revealing the energy pathways in the ecosystem. In addition, a better understanding of the factors controlling marine top predator populations will help species conservation and management. In this context, the use of ecosystem-based monitoring programmes (e.g. Fauchald et al. 2000, Ainley et al. 2005, Ballance et al. 2006) is one major way to acquire knowledge about the interplay between several components of marine ecosystems, where controlled experiments are difficult to undertake.

The PELGAS (PELagique GAScogne) research survey series is an annual monitoring survey programme that studies the pelagic ecosystems of the shelf of the Bay of Biscay (France), led by the French Research Institute for Exploitation of the Sea (IFREMER). During spring, acoustic methods are used to estimate the biomass of small pelagic fish species and, since 2003, information is collected simultaneously on abundance and distribution of marine predator populations. Today, a spatio-temporal time series of $6 \mathrm{yr}$ (2003 to 2008) is available, corresponding to $>10000$ nautical miles $(\mathrm{nmi} ; \mathrm{nmi}=1.852 \mathrm{~km}$ ) of at-sea transects sampled on the Bay of Biscay shelf.

The present study documents a general multivariate analysis of the top predator and small pelagic fish data collected during the PELGAS survey from 2003 to 2008. Due to the large amount of variables (small pelagic fishes, seabirds, cetaceans and fisheries) simultaneously collected, we used classical multivariate analysis of a series of k-tables (e.g. Dray et al. 2003, Thioulouse et al. 2004), in order to capture the most stable part of the sampled spatio-temporal pattern. The results are used to formulate hypotheses on the major prey-predator relationships that exist at the top of the Bay of Biscay marine food web. 


\section{MATERIALS AND METHODS}

PELGAS surveys. The annual French pelagic acoustic spring survey PELGAS has taken place since 2000, led by IFREMER on board the RV 'Thalassa', with the main aim of monitoring the abundance of anchovy Engraulis encrasicolus and sardine Sardina pilchardus in the Bay of Biscay. Other small pelagic fish species for which abundance is also monitored are: sprat Sprattus sprattus, horse mackerel Trachurus trachurus and mackerel Scomber scombrus. Survey strategy was based on previous surveys and standardised under the auspices of the ICES Working Group on Acoustic and Egg Surveys for Sardine and Anchovy in ICES Areas VIII and IX (Petitgas et al. 2009). The surveys consists of $\sim 3000 \mathrm{~km}$ of transects perpendicular to the coast. These transects regularly cover the continental shelf of the Bay of Biscay $\left(80000 \mathrm{~km}^{2}\right)$ in May (Fig. 1). The primary objective of PELGAS was to contribute to the evaluation of small pelagic fish populations in the Bay of Biscay by acoustic methods, but it has quickly evolved towards a general assessment of all components of the marine environment from plankton to top predators. During the survey, environmental information (e.g. temperature, salinity, fluorometry) is also routinely collected. Visual census of top predators (seabirds, marine mammals and fishing boats) has

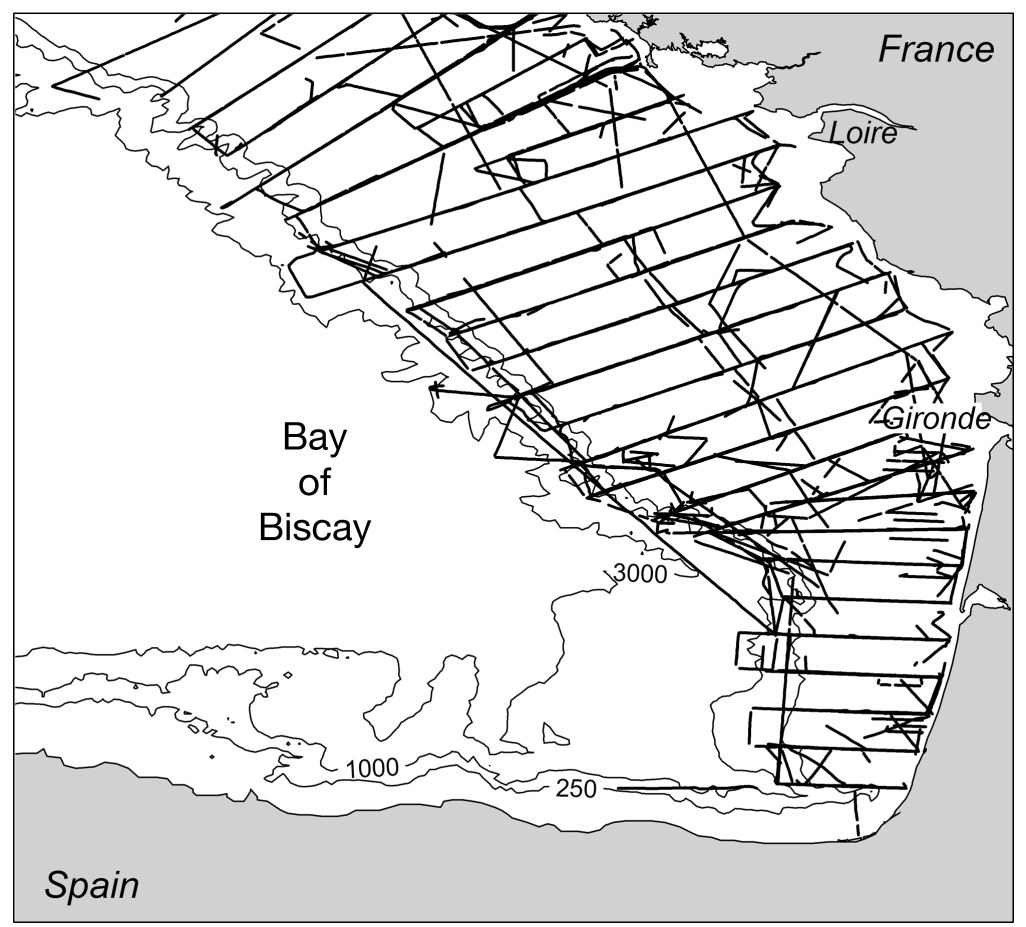

Fig. 1. Sampling scheme and study area. Transects surveyed by RV 'Thalassa' during the PELGAS surveys over the 6 yr (2003 to 2008) of the study period are shown (thick black lines). The 250, 1000 and $3000 \mathrm{~m}$ isobaths (thin black lines) are shown, delineating the location of the shelf-break area been routinely carried out since 2003. The present study focuses on the time period during which pelagic fishes and top predator data were recorded simultaneously, i.e. between 2003 and 2008.

Estimation of fish biomass using acoustic methods. Each year, the RV 'Thalassa' covers the same equally spaced transects $(20 \mathrm{~km}$ apart) traversing the entire shelf along the French coast of Biscay. Cross-shelf transect lines from the coast (20 m depth) to shelf break (250 $\mathrm{m}$ depth) are sailed during daytime at 10 knots. The acoustic equipment consists of hull-mounted SIMRAD EK60 split-beam transducers $(18,38,70,120$ and $200 \mathrm{kHz}$ ) with nominal beam angles of $7.5^{\circ}$ (except $11^{\circ}$ for $18 \mathrm{kHz}$ ). Details on the acoustic settings and procedures used can be found in Petitgas (2003). The continuously recorded acoustic backscattering along the transect lines are echo-integrated by layer and school (Massé et al. 1996) from the $38 \mathrm{kHz}$ frequency and echograms are scrutinised to select only those echoes that correspond to fish acoustic echo-traces following standard procedures (Simmonds \& MacLennan 2005). The echo-integration process is expressed as acoustic backscattered energy $\left(\mathrm{m}^{2} \mathrm{nmi}^{-1}\right)$ per elementary sampling unit (ESU). One ESU is $1 \mathrm{nmi}$ long, which corresponds to the finest achievable spatial resolution on board. Mid-water trawl hauls are performed to assign the echo-traces to species or groups of species in this mixed-species ecosystem. Also, the trawl catches provide the necessary biological data (length, weight and age by species) to convert the acoustic backscattered energy to fish abundance and biomass by species, length and age (Simmonds \& MacLennan 2005). Trawl hauls are associated to corresponding ESUs using expert knowledge (Massé 1988). The estimation process results in maps of fish biomass (tonnes $\mathrm{nmi}^{-2}$ ) for each small pelagic species, in 9 size classes, ranging from $<10 \mathrm{~cm}$ to $>45 \mathrm{~cm}$, with $5 \mathrm{~cm}$ increments. This information is available for each ESU along the transects for each year of the series.

Visual census of top predators. Sightings of top predators (seabirds, marine mammals and fishing vessels) were recorded during daylight, starting around 06:00 $\mathrm{h}$ and stopping around 22:00 $\mathrm{h}$ depending on daylight duration. Visual census for top predators was interrupted during the trawls and when visibility was poor (Beaufort sea state $\geq 6$ ).

Two observers (1 on the starboard side, 1 on the port side) searched for cetaceans, seabirds and fishing vessels ahead of the 
bow within an angle of $180^{\circ}$ (each observer covering $>90^{\circ}$ to ensure some overlap on either side of the bow) in $2 \mathrm{~h}$ shifts. During the 2003 and 2004 PELGAS surveys, observers were placed $14 \mathrm{~m}$ above sea level on the bridge. During the 2005 to 2008 surveys, observers had access to the upper bridge of the ship, $16 \mathrm{~m}$ above sea level and remained at this station if conditions were favourable. If the wind was too strong or if it rained, observers continued working from the bridge. All observers were experienced in at-sea surveys, and each team combined specialists of seabirds and marine mammals to ensure the most accurate identification of species. For each sighting, observers recorded the number of individuals, species composition, behaviour, and times of the observation, together with the distance and angle (estimated by eye and with an angleboard). Observers adapted their search effort primarily to detect cetaceans (e.g. scanning the sea surface only up to $500 \mathrm{~m}$ away from the ship) because they are the most cryptic targets but recorded all seabirds and fishing vessels detected. This strategy was chosen as a trade-off to collecting as much data on several ecosystem components as possible, given the limited availability of space for personnel on the vessel. Seabirds and cetaceans were identified to species level, and in the case of fishing vessels, 2 main categories were encountered: trawlers and gillnetters. Long-line and trap fishing were also recorded but they were rarely present in the surveyed area (corresponding to $<1 \%$ of the sightings of fishing vessels) and are therefore excluded from our analysis. Great attention was paid to the recording of seabird and cetacean behaviour at the moment of sighting, especially to identify individuals following or attracted by the research vessel (e.g. individuals engaged in a straight movement toward the fishing vessel).

GPS positions of the sightings were extracted from the GPS tracks recorded by the research vessel. Toppredator data were extracted at the same spatial scale as prey data. We used the number of individuals of each predator species counted within each ESU, excluding all predators whose behaviour was recorded as attracted by the research vessel, as a measure of top predator relative density.

For the Fisheries variable, sightings of trawlers and gillnetters $(77 \%$ and $23 \%$ of fishing vessel sightings respectively) were pooled together for the calculation of fisheries relative density, due to the high proportion of unidentified fishing vessels in the first years of the series. Sightings of terns (Sterna sandvicensis and S. hirundo) and shearwaters (Puffinus gravis, P. griseus, P. mauretanicus, and P. puffinus) were also pooled together in 2 categories ('Sterna spp.' and 'Puffinus spp.', respectively) due to the scarcity of individual species sightings.
Selection of variables. Prior to analysing our dataset, we first searched for the most pertinent prey variables, because the simple combination of all prey species $\times$ size classes led to 51 variables, most of them corresponding to very low biomasses, and therefore not relevant to study prey-predator interactions. We then excluded combinations of prey species $\times$ size classes that did not fit the following 2 criteria: to be observed each year in the Bay of Biscay, and to account for at least $0.5 \%$ of the total estimated small pelagic biomass. By applying these 2 criteria we ended up with 18 prey variables: Engraulis encrasicolus 10-15 cm, and 15-20 cm; Micromesistius poutassou 15-20 cm; Sardina pilchardus $10-15 \mathrm{~cm}, 15-20 \mathrm{~cm}$, and 20-25 cm; Scomber scombrus 15-20 cm, 20-25 cm, 25-30 cm, $30-35 \mathrm{~cm}$, and 35-40 cm; Sprattus sprattus $<10 \mathrm{~cm}$, and 10-15 cm; and Trachurus trachurus $10-15 \mathrm{~cm}$, 15-20 cm, 20-25 cm, 25-30 cm, and 30-35 cm. Together, these variables account for $>98 \%$ of the estimated small pelagic biomass in the Bay of Biscay. Fish biomass was expressed in $\mathrm{kg} \mathrm{nmi}{ }^{-2}$.

We did not perform any variable selection for top predators, because excluding species with low abundance would exclude species of conservation interest. We therefore kept the 13 marine top predator taxa recorded in the Bay of Biscay: Larus argentatus, L. fuscus, Catharacta skua, Puffinus spp., Rissa trydactyla, Sula bassana, Sterna spp., Globicephala melas, Delphinus delphis, Tursiops truncatus, Fulmarus glacialis, Hydrobates pelagicus and Uriaa aalge. By adding the fishing vessels, we ended up with 14 predator variables. However, individuals following or attracted by the research vessel were excluded (Tasker et al. 1984). Predator relative density was expressed in number of individuals counted per nautical mile (ind. $\mathrm{nmi}^{-1}$ ).

Prey and predator spatio-temporal variability. Firstly, using the data extracted at the $1 \mathrm{nmi}$ scale (as the ESU), the mean relative abundance of each variable was calculated for each year, together with the $95 \%$ confidence intervals. Confidence intervals were calculated using a non-parametric bootstrap, e.g. 999 pseudo-samples taken from the ESU of each year. Secondly, we illustrated the spatial distribution of the analysed variables of small pelagic fishes and top predators, to provide a description of their preferred areas in the Bay of Biscay.

After extracting the data at the ESU level and considering only transects where prey and predators were simultaneously sampled, we ended up with 8810 ESUs across the $6 \mathrm{yr}$, i.e. $>16000 \mathrm{~km}$ of transects (see Table 1). These data were used to map the variables for each prey and predator. We used ordinary kriging (Cressie 1993) to interpolate prey log biomass and predator log-relative densities. We pooled together all years (2003 to 2008) to obtain 1 map for each variable. 
Log-transformation was applied to smooth the effect of strong local aggregations that can be observed with schooling fishes or with seabirds. Predictions were calculated on a lattice composed of $5 \times 5 \mathrm{~km}$ cells. Ordinary kriging was performed with R software (R Development Core Team 2008), using the gstat package (Pebesma \& Wesseling 1998).

Extracting data for multivariate analysis. Data extracted at the ESU spatial scale were not well suited for multivariate analysis because of the very high proportion of zero values they contained, especially with the rarest species. We therefore searched for a tradeoff scale that minimised the occurrence of zero values in the data while offering enough spatial detail. After a trial and error process, we averaged prey biomass and predator relative density into a grid composed of 30 cells of $2500 \mathrm{~km}^{2}(50 \times 50 \mathrm{~km})$, which is a spatial scale that matches the scale of the major oceanographic features in the Bay of Biscay (Koutsikopoulos \& Le Cann 1996, Planque et al. 2004, Puillat et al. 2004). In total, prey and predator variables were averaged within 169 grid cells during the $6 \mathrm{yr}$. We therefore obtained for a given year 2 tables of $n$ rows and $p$ columns, $n$ being the number of grid cells documented that year and $p$ the number of variables (18 for prey, 14 for predators). With 6 yr of data, we subsequently obtained a sequence of 6 paired ecological tables well suited to perform a STATICO analysis (Thioulouse et al. 2004).

Overview of STATICO method for multivariate analysis. STATICO (Thioulouse et al. 2004) is a method designed to analyse a series of paired ecological tables. The objective of the method is to find the stable part in the dynamics of the relationships between 2 sets of variables, here marine top predators and small pelagic fishes. From a statistical point of view, STATICO is a multi-table analysis performed on the series of crosstables resulting from the co-inertia analysis of each pair of tables. The STATICO method consists of 3 steps:

(1) each table is first analysed by a basic analysis, a 1table method such as principal component analysis (PCA);

(2) each pair is then linked by a co-inertia analysis (Dray et al. 2003), producing a cross-table at time $t$, and the co-inertia matrix $W_{t}$

(3) since a cross-table $W_{t}$ is produced for each date, a partial triadic analysis (PTA; Thioulouse \& Chessel 1987, Thioulouse et al. 2004) is used to analyse the series of cross-tables $W_{t t^{\prime}}$.

A detailed description of STATICO analysis can be found in Thioulouse et al. (2004) together with an example application. If Step 3 is relatively straightforward (Thioulouse et al. 2004), Steps 1 and 2 require several user-made choices (Dray et al. 2003) that we explain in detail in the following section.
Let us denote as $X_{t}(n \times p)$ the table that contains at each year $t$ the relative biomass values for $p=18$ prey species (columns) in $n$ cells of $50 \times 50 \mathrm{~km}=2500 \mathrm{~km}^{2}$ covering the study area (rows). Let us denote as $Y_{t}(n \times q)$ the corresponding predator table that contains the relative density values for $q=14$ predator species in the same cells.

$X_{t}$ and $Y_{t}$ are scaled by columns so as to produce a species profile table (see Dolédec et al. 2000, Dray et al. 2007). By using a species profile table, we assume nonlinear relationships between prey and predators, and we focus the analysis on the relative distribution of species over cells, in order to reveal species associations (Dray et al. 2003). No particular weights are given to the rows: each spatial location (cell) has the same importance. The series of co-inertia matrix $W_{t}(p, p)$ can be written as: $W_{t}=$ $X_{t}^{T} Y_{t} Y_{t}^{T} X_{t} / n^{2}$. The decomposition of $W t$ achieved by the co-inertia analysis aims to find a vector $u 1$ in the prey space and $v 1$ in the predator space with maximal coinertia. The second and further pairs of vector $(u 2, v 2)$ maximises the same quantity, but with orthogonal constraints (Dray et al. 2003). At this point, PTA (Thioulouse et al. 2004 ) is applied to analyse the series of cross-tables $W_{t t}$.

First, to characterise the consistency in time of the series of cross-tables $W_{t t^{\prime}}$ a scalar product is defined: $T_{t t^{\prime}}=\operatorname{Trace}\left(W_{t}^{T} W_{t^{\prime}}\right)$. The resulting PCA of matrix $T$ constructs a factorial space ('inter-structure') which represents the similarity/dissimilarity between coinertia matrices $W_{t}$. The elements of the first eigenvector of $T, \alpha_{t}$ provide weights that are used to estimate an average co-inertia matrix $W_{c}$ ('compromise'). $W_{C}$ provides the structure common to all matrices $W_{t}$ and represents a time-consistent co-inertia matrix. It is obtained by a linear combination of the matrices $W_{t}$ : $W_{c}=\Sigma_{t} \alpha_{t} W_{t}$. The PCA of $W_{c}$ constructs a factorial space, the 'compromise', in which compromise positions over time of the $p$ prey species and of the $q$ predator species can be plotted. These positions are used to identify prey-predator spatial associations.

Furthermore the 'trajectories' along the series of prey and predators can also be represented around their 'compromise' position. In doing so, the departure from the average structure is characterised, which can be interpreted as a graphical representation of the temporal variability of the averaged 'compromise' positions. To examine the inter-annual variability associated with the prey-predator associations, we plotted the projected location of prey and predators at the $6 \mathrm{yr}$ on the factor map of the PCA of the compromise. The prey-predator pairs were chosen according to the position of prey and predators on the compromise, so as to represent the most relevant prey-predator associations.

The STATICO analysis was done with $\mathrm{R}$ software (R Development Core Team 2008) and the ade4 package (Chessel et al. 2004, Dray et al. 2007). 


\section{RESULTS}

\section{Spatio-temporal variability of prey and predators in the Bay of Biscay}

The average fish biomass estimated by acoustic methods in the Bay of Biscay shows that Scomber scombrus is the most important small pelagic fish in
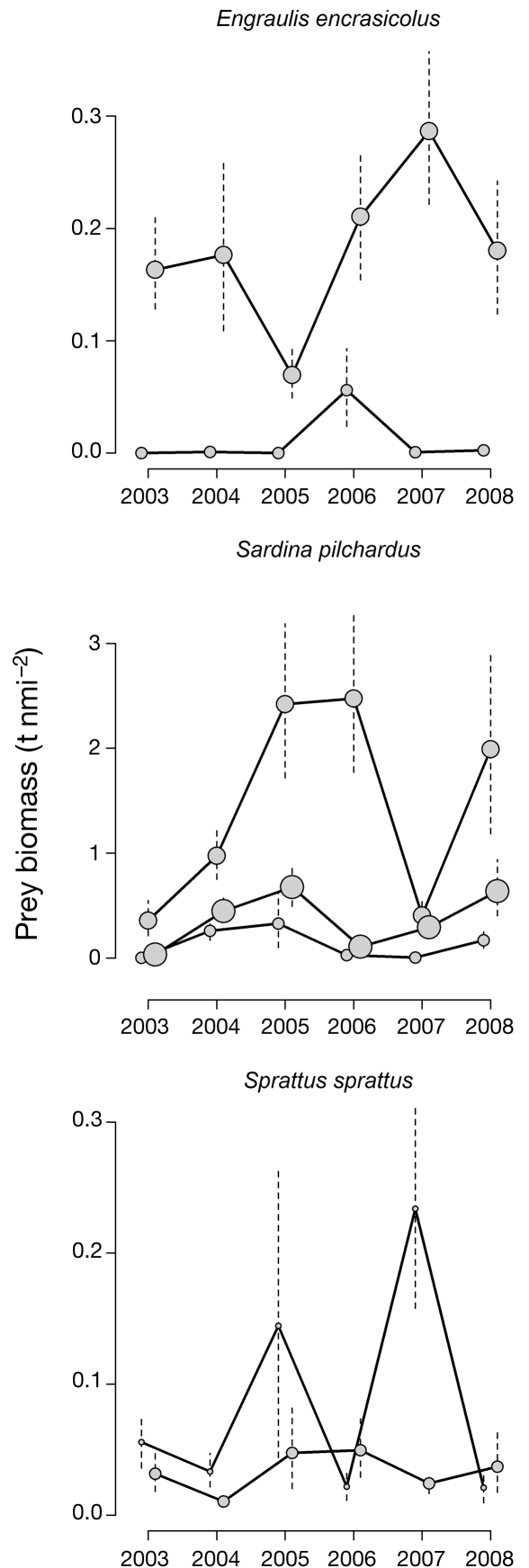

spring, followed by Sardina pilchardus and Trachurus trachurus (Fig. 2). However, the biomass of the whole small pelagic community is subject to important temporal fluctuations (Fig. 2), with years of high biomass (e.g. 2004, 2005, 2006) alternating with years of low-tomoderate biomass $(2003,2007,2008)$. Also, some discrepancies can be seen within a species between size classes: the dominant size class in Scomber scombrus
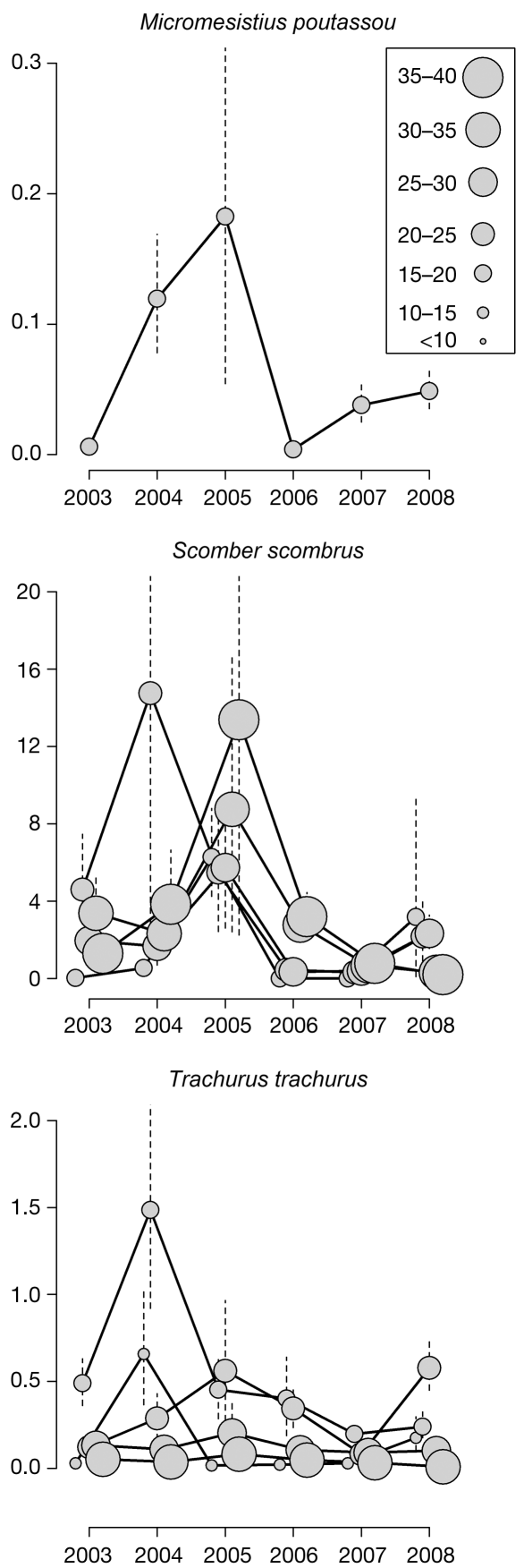

Fig. 2. Average prey biomass for the whole study area each year. Circle size (filled grey circle) is proportional to prey size class, ranging from $<10 \mathrm{~cm}$ to $35-40 \mathrm{~cm}$ (overlapping data have been offset for clarity); $95 \%$ confidence intervals are shown (vertical dashed line), calculated using a non-parametric bootstrap 
was $20-25 \mathrm{~cm}$ in 2004, and $25-30 \mathrm{~cm}$ in 2005. Sardina pilchardus of $15-20 \mathrm{~cm}$ were solely responsible for the increase in this species' biomass in 2005 and 2006, the 2 other size classes remaining fairly stable in comparison. For Trachurus trachurus, a significant increase in biomass in 2004 was only observed in the smaller size classes, as for Sprattus sprattus in 2004 and 2007. Conversely, most of the biomass of Engraulis encrasicolus was represented by large fish, reflecting the belowaverage recruitment of this species in recent years, which led to the closure of the fishery in the area from June 2006 to December 2009 (ICES 2010).

The predators Morus bassanus, Larus fuscus, and to a lesser extent Delphinus delphis, were the most abundant predators in the Bay of Biscay (Fig. 3). Again, fluctuations in predator relative densities were evident, both in frequent and rare seabird species and in marine mammals (Fig. 3). The temporal variation in the abundance of the predator community seems to alternate between high and low values, with L. fuscus, $M$. bassanus and $D$. delphis exhibiting the most important inter-annual variations, even if with wide confidence intervals. In birds, shifts in relative densities were observed in common and rare species, with peaks in relative densities in 2004, 2006 and 2008. Among the frequently observed seabird species, L. fuscus and $M$. bassanus showed higher temporal variability than $L$. argentatus and Fulmarus glacialis. In cetaceans, peaks were observed in 2003, 2005 and 2008. Observation conditions were fairly similar from year to year regarding Beaufort sea state, except in 2005 when bad weather predominated during the survey (Table 1). It
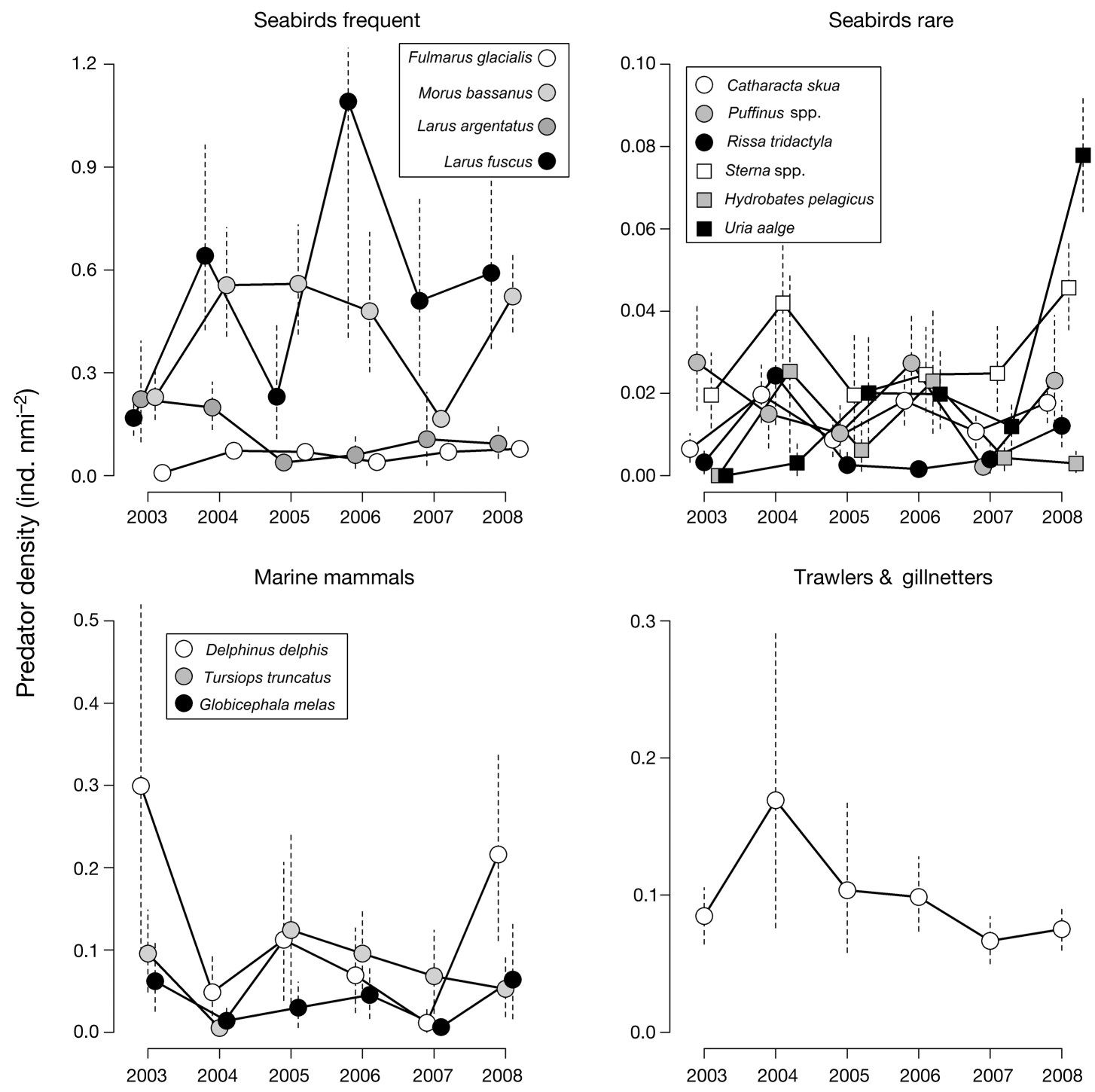

Trawlers \& gillnetters

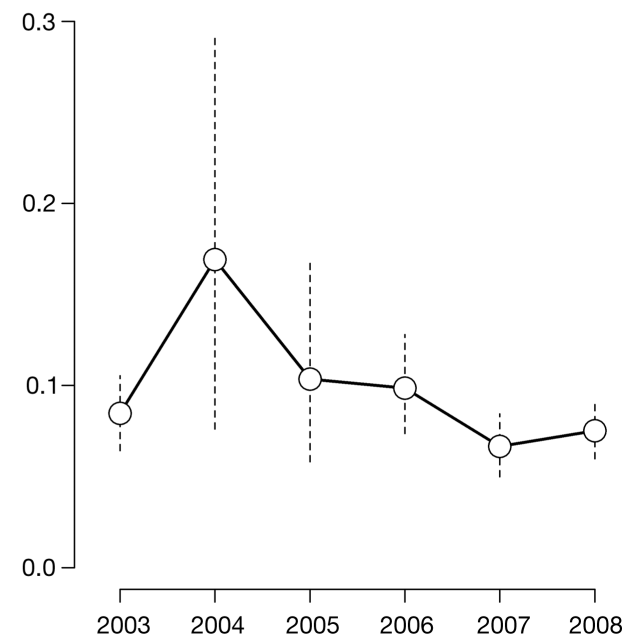

Fig. 3. Average predator relative density for the whole study area each year. $95 \%$ confidence intervals are shown (vertical dashed line), calculated using a non-parametric bootstrap 
Table 1. Search effort $(\mathrm{km})$ achieved in each year when both prey and predators were simultaneously sampled, stratified by Beaufort sea state. 'Good' observation conditions were considered to be those when Beaufort sea state $\leq 3$

\begin{tabular}{|c|c|c|c|c|c|c|c|c|c|}
\hline \multirow{2}{*}{ Year } & \multicolumn{7}{|c|}{ - Beaufort sea state } & \multirow{2}{*}{ Total } & \multirow{2}{*}{$\begin{array}{c}\text { Good obs. } \\
\text { conditions (\%) }\end{array}$} \\
\hline & 0 & 1 & 2 & 3 & 4 & 5 & 6 & & \\
\hline 2003 & 91 & 589 & 1095 & 557 & 311 & 189 & 56 & 2888 & 80.7 \\
\hline 2004 & 0 & 146 & 591 & 1350 & 322 & 428 & 119 & 2956 & 70.6 \\
\hline 2005 & 19 & 315 & 376 & 326 & 693 & 596 & 69 & 2394 & 43.2 \\
\hline 2006 & 13 & 333 & 1254 & 580 & 224 & 46 & 17 & 2467 & 88.4 \\
\hline 2007 & 157 & 832 & 198 & 506 & 30 & 594 & 241 & 2558 & 66.2 \\
\hline 2008 & 152 & 591 & 769 & 1013 & 269 & 187 & 76 & 3057 & 82.6 \\
\hline
\end{tabular}

might therefore be possible that relative cetacean densities in 2005 were underestimated. In the case of fisheries, relative densities of fishing vessels appeared relatively stable throughout, apart from a peak (associated with a wide $95 \%$ confidence interval) observed in 2004

The high variability associated with prey and predator abundance was not only temporal, but also spatial (Figs. 4 \& 5). It could nonetheless be visually summarised according to the major oceanographic features of the Bay of Biscay: the shelf-break, straight in the northern part, and U-shaped in the south (see Certain et al. 2007, 2008) and the Loire and Gironde river plumes (Planque et al. 2004, Puillat et al. 2004).

For Scomber scombrus and Trachurus trachurus, small-sized individuals were mainly distributed in the central and northern part of the continental shelf, whereas larger individuals clearly showed a preference for the shelf-break area, especially in the case of Scomber scombrus. Sardina pilchardus was associated with both coastal and shelf-break areas with the smallest fish $(<15 \mathrm{~cm})$ being observed only in coastal areas. Engraulis encrasicolus mainly occurred in coastal, southern areas (Fig. 4). Coastal areas, and especially river plumes, were mainly populated by Sardina pilchardus, E. encrasicolus and Sprattus sprattus, while other fish species were not found in these areas (Fig. 4).

Spatial patterns of predator species were a bit more complex and fragmented than the spatial patterns of the prey (Fig. 5). Nonetheless, some general patterns could be identified, with species associated with coastal and shallower areas (Delphinus delphis, Puffinus spp., Larus argentatus, Uria aalge), species associated with pelagic areas (Tursiops trucatus and Globicephala melas, both being closely related to the shelf break; Fulmarus glacialis), species showing a north-south gradient of distribution (Rissa tridactyla, Sterna spp.) and species widely distributed throughout the whole Bay of Biscay (fisheries, Morus bassanus, L. fuscus, Catharacta skua).

\section{STATICO analysis}

\section{Compromise}

According to their position on the factor map of the PCA of the compromise (Fig. 6), 4 groups of preypredator associations were identified.

Group 1 consisted of species that were positively associated with both PC1 and PC2: Engraulis encrasicolus 10-15 cm mainly associated with Sterna spp., and to a lesser extent with fisheries and Catharacta skua.

Group 2 consisted of species positively associated with PC1 and slightly negatively associated with PC2, and also associated with negative values on PC3. In this group, prey species were small-sized fishes (Sardina pilchardus 10-20 cm, Sprattus sprattus $10-15 \mathrm{~cm}$ ), and predators included both marine mammals (Delphinus delphis) and seabirds (Uria aalge, Larus argentatus and Hydrobates pelagicus).

Group 3 was composed of species negatively associated with PC2, and positively associated with PC3. It included Morus bassanus, and 2 prey of intermediate size: Trachurus trachurus 10-20 cm, and Scomber scombrus $25-30 \mathrm{~cm}$.

Group 4 consisted of species that were mainly found in the shelf break area, i.e. Tursiops truncatus, Trachurus trachurus $25-35 \mathrm{~cm}$ and Scomber scombrus $35-40 \mathrm{~cm}$.

The remaining species mostly presented an intermediate position between these 4 groups and were therefore hard to characterise.

\section{Inter-annual variability}

Fig. 7 illustrates the high variability of these prey-predator associations: for Group 1, Sterna spp. and Engraulis encrasicolus were tightly related in 2004 and 2006, but this relationship tended to disappear in the remaining years, and their positions 

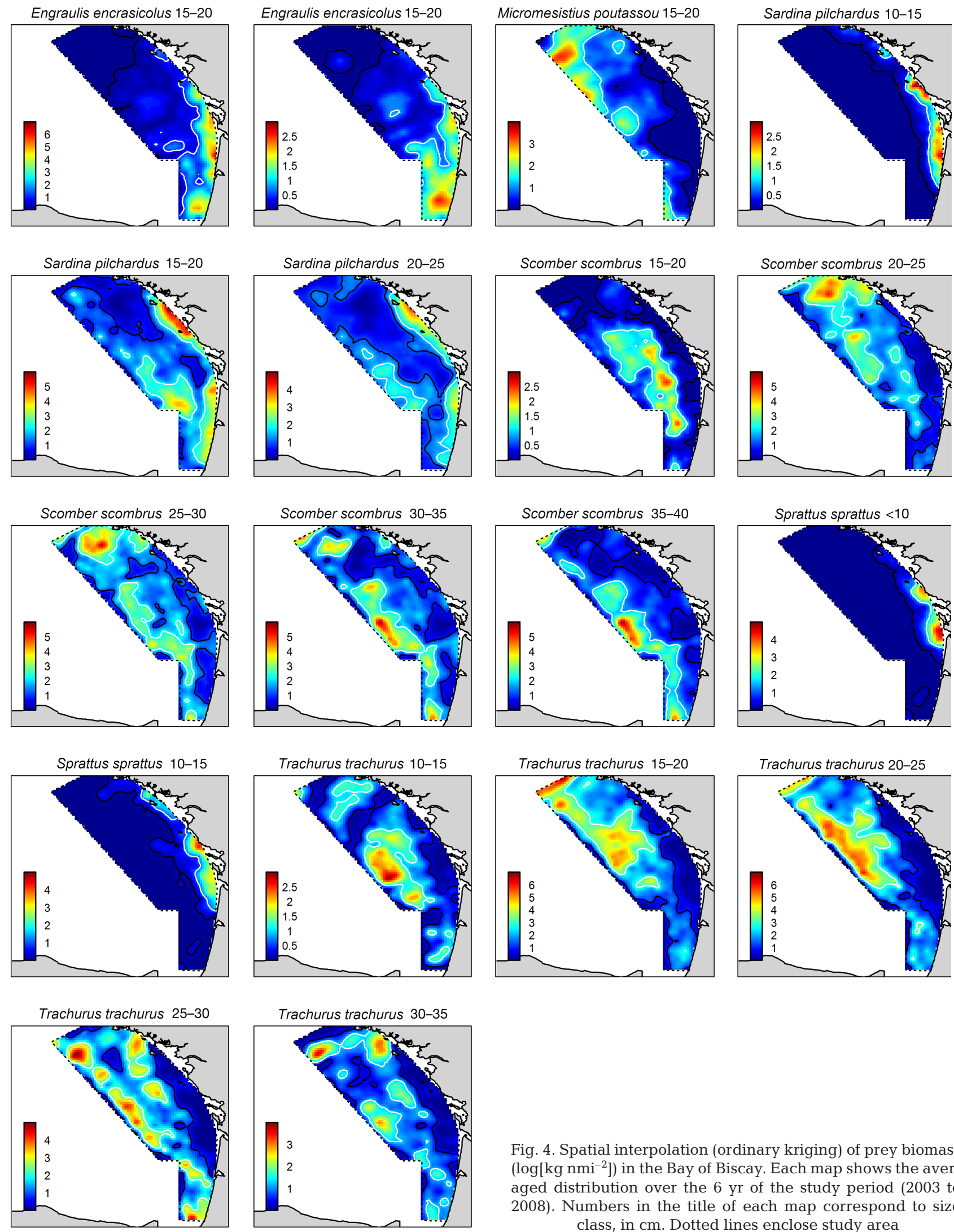

Fig. 4. Spatial interpolation (ordinary kriging) of prey biomass $\left(\log \left[\mathrm{kg} \mathrm{nmi}^{-2}\right]\right)$ in the Bay of Biscay. Each map shows the averaged distribution over the $6 \mathrm{yr}$ of the study period (2003 to 2008). Numbers in the title of each map correspond to size class, in $\mathrm{cm}$. Dotted lines enclose study area 
on the first axis were even opposite in 2008 (Fig. 7a). For Group 2 (Fig. 7b-e), most of the prey-predator associations were observed in 2005 and 2008, when both Delphinus delphis and Uria aalge were associated with Sardina pilchardus $10-20 \mathrm{~cm}$ and Sprattus sprattus 10-15 cm, but these associations were less clear in the remaining years. In Group 3 (Fig. 7g,h), close associations between Morus bassanus and Trachurus trachurus 15-25 cm were observed in 2004 and 2006, while a negative association was observed in 2005, when Morus bassanus was strongly associ- ated with Scomber scombrus 25-30 cm. In Group 4, the association between Tursiops truncatus and large Scomber scombrus (Fig. 7i) was extremely strong on PC1 in 2005, and also to a lesser extent in 2006. The remaining years were characterised by a lack of structure.

From this analysis, it appears that the overall structure of the prey-predator community in spring in the Bay of Biscay varies throughout the years, ranging from years with weak structure where some groups may even be considered to be overlapping (e.g. 2003,
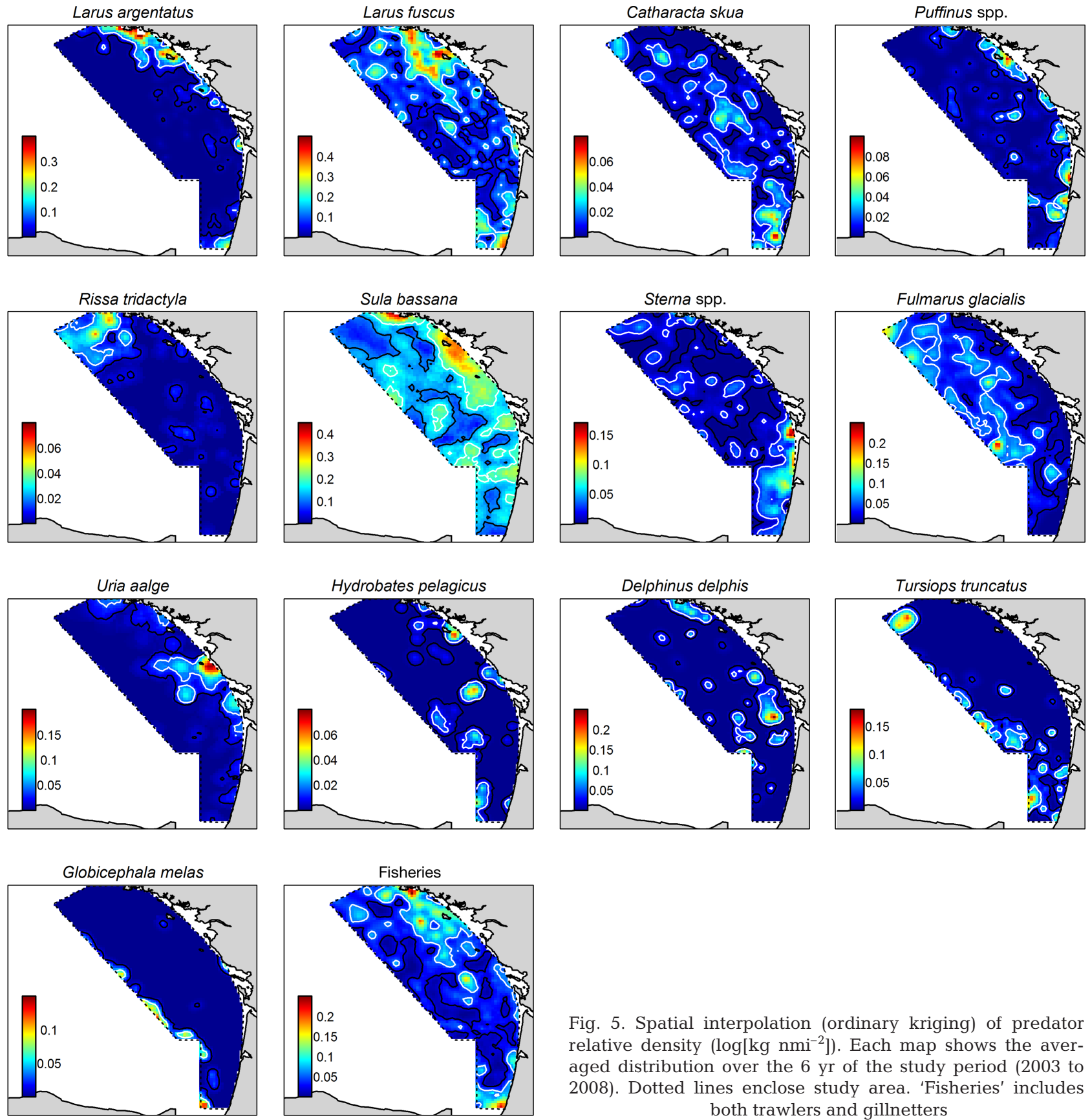

Fig. 5. Spatial interpolation (ordinary kriging) of predator relative density $\left(\log \left[\mathrm{kg} \mathrm{nmi}^{-2}\right]\right)$. Each map shows the averaged distribution over the $6 \mathrm{yr}$ of the study period (2003 to 2008). Dotted lines enclose study area. 'Fisheries' includes both trawlers and gillnetters 
$2004,2007)$ to years where groups are much more structured $(2005,2006$ and 2008, depending on the groups). Of course, some differences exist between groups, with the trajectories of Groups 1 and 2 appearing more stable (e.g. evolving in a smaller space in the compromise) than Groups 3 and 4.

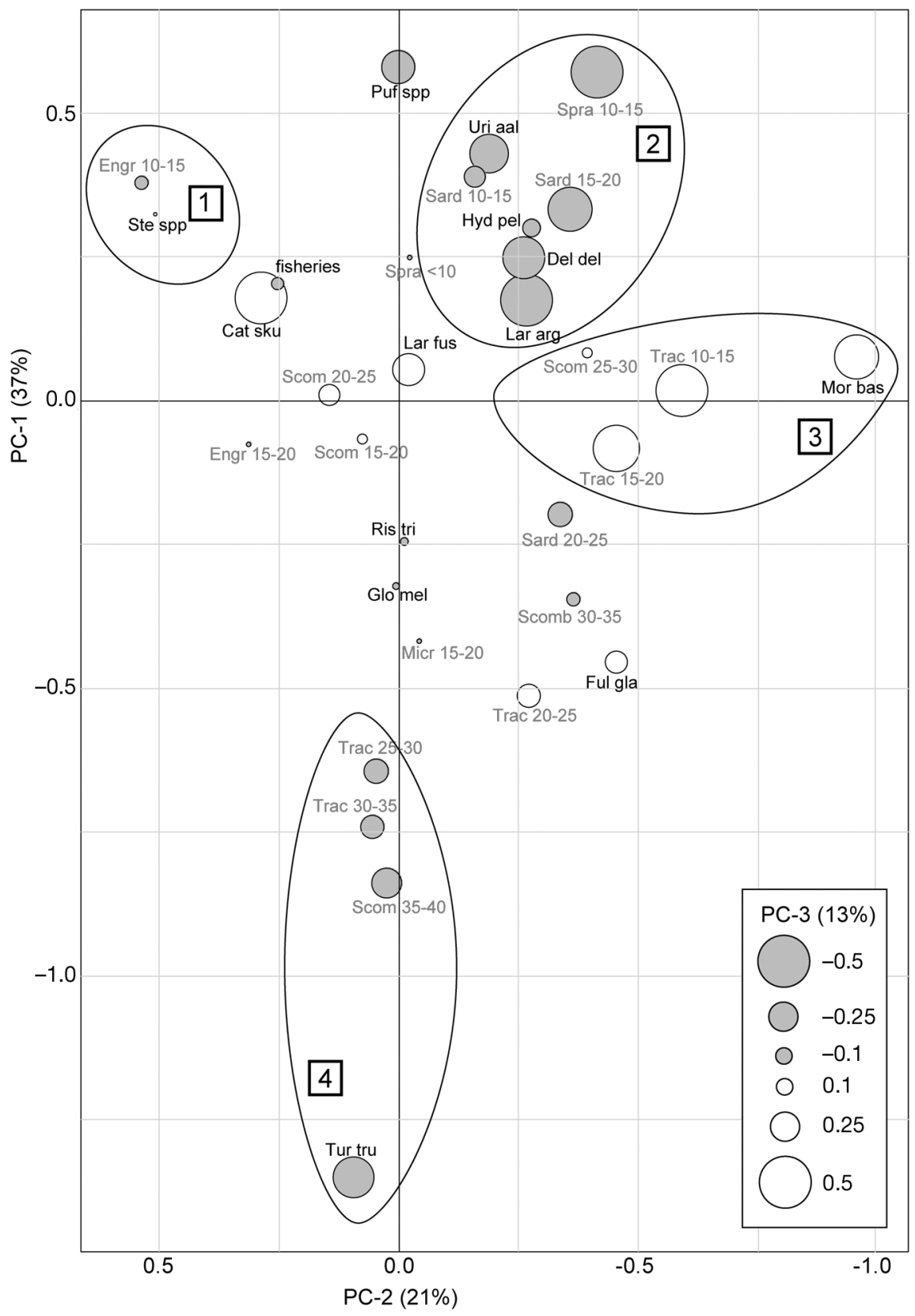

Fig. 6. Position of prey and predator variables on the 'compromise' factorial space (PC1, PC2 and PC3) of the STATICO analysis. Contribution of each axis, in terms of total variance explained, is shown in \%. Prey: Engr = Engraulis encrasicolus, Micr $=$ Micromesistius poutassou, Sard $=$ Sardina pilchardus, Scom $=$ Scomber scombrus, Spra $=$ Sprattus sprattus, Trac $=$ Trachurus trachurus. Numbers after prey names correspond to size class in $\mathrm{cm}$. Predators: Cat sku = Catharacta skua, Del del $=$ Delphinus delphis, fisheries $=$ trawlers and gillnetters, Ful gla $=$ Fulmarus glacialis, Glo mel = Globicephala melas, Hyd pel = Hydrobates pelagicus, Lar arg = Larus argentatus, Lar fus $=$ L. fuscus, Mor bas = Morus bassanus, Puf spp = Puffinus spp., Ris tri = Rissa tridactyla, Ste $\mathrm{spp}=$ Sterna spp., Tur tru = Tursiops truncatus, Uri aal = Uria aalge. Numbers in squares correspond to prey-predator groups identified in the present study

\section{DISCUSSION}

\section{Prey-predator associations in the Bay of Biscay}

The structure between prey and predators evidenced by the STATICO analysis revealed a highly complex organisation, subject to an obvious inter-annual variability. On the factor map of the PCA of the compromise, the variability of this community is described using 4 prey-predator groups whose locations were distinct. With such a complex prey-predator community, it may be difficult to clearly understand the ecological properties associated with each principal component, especially because all variables included in the analysis present complex spatial patterns (e.g. Figs. 4 \& 5) likely to exhibit temporal variations (our Figs. 3 \& 4, Certain et al. 2008). However, the main features of these spatial patterns can be identified and related to the broad oceanographic features of the Bay of Biscay.

PC1 clearly opposes species with pelagic distribution and strong shelfbreak associations (e.g. Tursiops truncatus, large Scomber scombrus and Trachurus trachurus) to more coastal species known to be related to mesoscale features such as river plumes (Engraulis encrasicolus, Sprattus sprattus and small Sardina pilchardus, Planque et al. 2007; Uria aalge, Bellier et al. 2010; and Delphinus delphis, Certain et al. 2008). PC2 opposes species with more coastal and southern spatial distribution (Engraulis encrasicolus, Sterna spp.) to species presenting moderate to high relative abundance in the central and north part of the bay (Morus bassanus, small Trachurus trachurus). PC3 (only illustrated in the plot of the compromise, Fig. 6) opposes species with a strong east-west gradient in their spatial distribution (either coastal or shelf-break species: Tursiops trunca- 
a) Stema spp. \& Engraulis encrasicolus 10-15

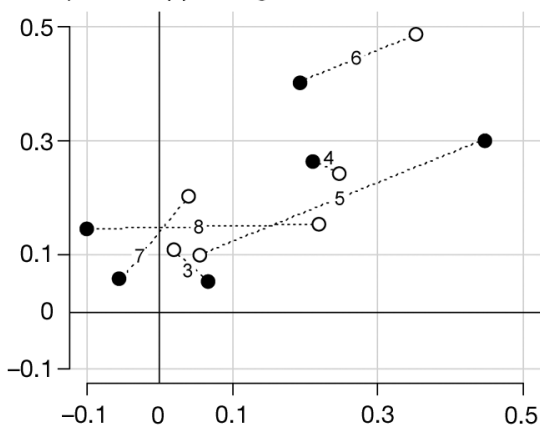

d) Uria aalge \& Sardina pilchardus $10-15$

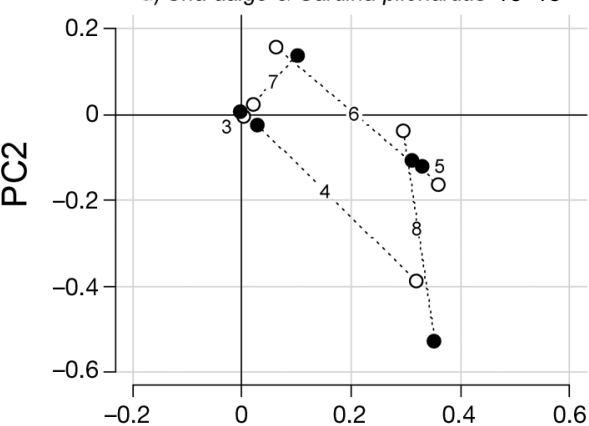

g) Morus bassanus \& Trachurus trachurus 20-25

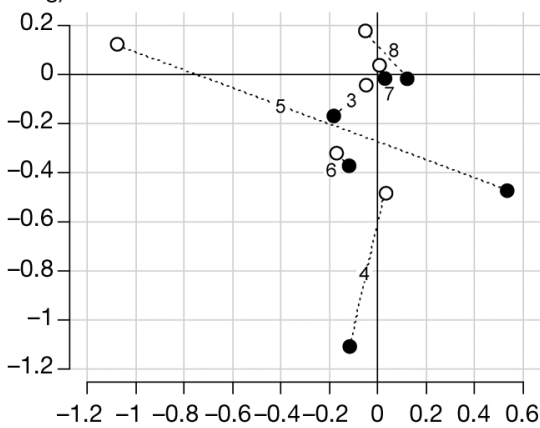

b) Delphinus delphis \& Sardina pilchardus $15-20$

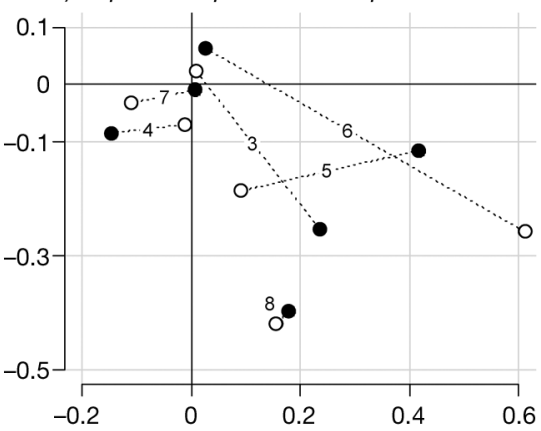

e) Uria aalge \& Sprattus sprattus $10-15$

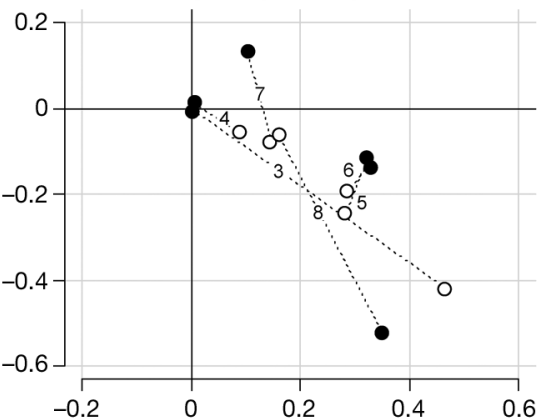

h) Morus bassanus \& Scomber scombrus 25-30

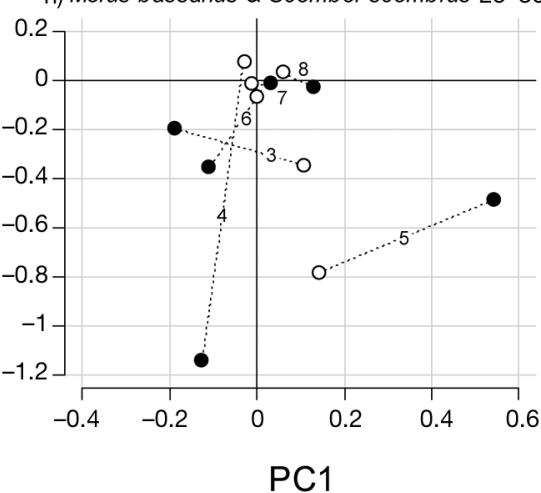

c) Delphinus delphis \& Sprattus sprattus $15-20$

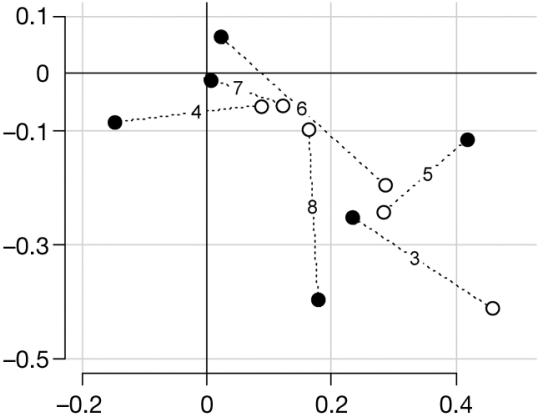

f) Morus bassanus \& Trachurus trachurus $15-20$

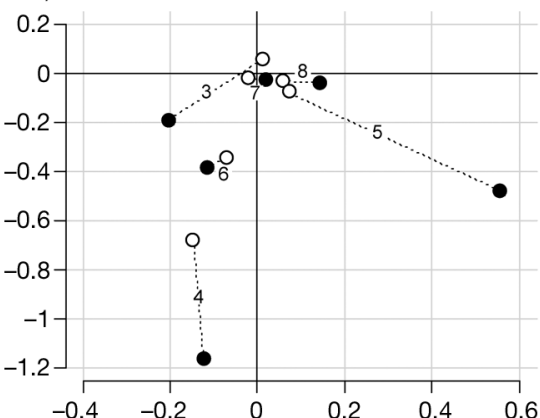

i) Tursiops truncatus \& Scomber scombrus $35-40$

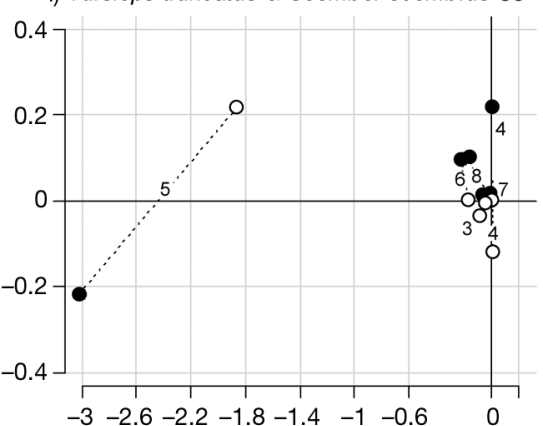

Fig. 7. Trajectories of prey (०) and predator (•) variables in the 'compromise' factorial plan (PC1 and PC2) each year. Each plot corresponds to a predator-prey pair. Numbers correspond to years ( 3 to $8=2003$ to 2008). Predator and prey locations in the same year are linked with a dotted line

tus, small Sardina pilchardus, Sprattus sprattus and D. delphis) to species much more widely distributed in the Bay of Biscay (Catharacta skua, M. bassanus, Trachurus trachurus).

Group 1 links together a fish stock (Engraulis encrasicolus) that has a high commercial value and that has been depleted in recent years, to Sterna spp. (e.g. $S$. sandvicensis and $S$. hirundo), and also to a lesser extent to Catharacta skua and to fisheries. Indeed, these species and the fisheries show high densities in the southern part of the bay, especially in coastal areas (Figs. 4 \& 5). Here, both trawlers and gillnetters operate, with gillnetters present in a more coastal distribu- tion (Léauté 1998). The E. encrasicolus fishery has been closed since 2006, so no direct link can exist between this species and the fishing fleet after this year. But in the south of the bay, trawlers and gillnetters are certainly targeting the areas where anchovies, terns and skuas can be found. The complex interactions between these species in the south of the bay could be explained as follows. In spring, Sterna spp. are probably relying on E. encrasicolus, as they are small fish with high energetic value whose size matches the prey size usually targeted by Sterna spp. (Snow \& Perrins 1998, Limmer \& Becker 2009). Sterna spp. are also among the favourite targets of kleptopar- 
asitic seabirds such as C. skua (Belisle 1998, Furness \& Hamer 2003). Furthermore, both Sterna spp. and C. skua use fisheries discards (Valeiras 2003). It is likely that, in addition to being an important predator for small pelagic fishes, fisheries in the south of the bay play a major role in providing food to both Sterna spp. and C. skua. Therefore, the system of anchovy-ternskua-fishery in the south of the bay is probably a suitable and sensitive case study to investigate the implementation of ecosystem-based fisheries management at a local scale.

Group 2 links together small pelagic fishes with coastal predators. The association between Delphinus delphis, Uria aalge, Sardina pilchardus and Sprattus sprattus is in accordance with previous studies on the diet of these 2 predator species $D$. delphis and $U$. aalge (i.e. small pelagic fishes of length $0-20 \mathrm{~cm}$ with high energetic content; see Lorentsen \& Anker-Nilssen 1999, Lance \& Thompson 2005, Pusineri et al. 2007, Meynier et al. 2008). The occurrence of Hydrobates pelagicus in this group may be due to the fact that they target similar prey to Sardina pilchardus (i.e. euphausiids and copepods; d'Elbée \& Hemery 1997, Palomera et al. 2007, Espinoza et al. 2009). The occurrence of Larus argentatus is also probably circumstantial: it is a coastal species that forages in both the marine and the terrestrial environment. When at sea, it is not surprising that it targets coastal productive areas where Sardina pilchardus and Sprattus sprattus can be found in abundance.

Group 3 corresponds to the most ubiquitous species, at least in terms of spatial distribution (Fig. 5). Indeed, Morus bassanus and Trachurus trachurus are widely distributed throughout the Bay of Biscay. Moreover, the length of T. trachurus in this group $(15-25 \mathrm{~cm})$ is consistent with the hypothesis of a trophic relationship, since $T$. trachurus of size 10-20 cm may indeed be consumed by M. bassanus (e.g. Bunce 2001, Hamer et al. 2006). This group of generalist species could even be extended to include Larus fuscus, according to its position on PC3.

Group 4 is formed by large pelagic fishes (Trachurus trachurus 25-35 cm, Scomber scombrus 35-40 cm) and by Tursiops truncatus and it groups together species associated with the shelf break. Previous dietary analysis also suggested that Tursiops truncatus consume a large proportion of large T. trachurus in the Bay of Biscay (Spitz et al. 2006). The association between Tursiops truncatus and S. scombrus may only be a circumstantial association. Indeed, S. scombrus use the shelf break as a migratory pathway between the Bay of Biscay and the Celtic Sea (Reid et al. 1997, Uriarte \& Lucio 2001) and both their occurrence and abundance in the Bay of Biscay in spring therefore depend on the timing of their migration. Furthermore, S. scombrus only marginally occur in the diet of Tursiops truncatus, compared to Trachurus trachurus (Spitz et al. 2006).
Several other prey size classes or predator species were difficult to clearly associate to a group. This is the case for species close to the PCA graph origin, such as Larus fuscus and Scomber scombrus 15-25 cm, which can be explained by their very wide distribution together with their probable generalist feeding behaviour. These species may not be strongly associated with any habitat or prey, and therefore are found in the centre of the compromise. Other prey such as Sardina pilchardus 20-25 cm, Scomber scombrus 30-35 cm and Trachurus trachurus $20-25 \mathrm{~cm}$ are placed between 2 groups (Groups 3 and 4), which suggests that they are probably equally targeted by the predators of Groups 3 and 4, Morus bassanus and Tursiops truncatus.

\section{Temporal variability of prey-predator associations}

The temporal variability analysis illustrated a high inter-annual variability in the group structure and group-specific differences in this variability (Fig. 7), which perfectly illustrates the great complexity and variability associated with any marine ecosystem. Even though several prey-predator associations occurred with high frequency in the long run, these associations are also ephemeral, dynamic, and may not be observed at all in a given year. Despite this large variability, our findings open a way towards further research questions and needs.

What are the factors responsible for the yearly shifts between strong to weak prey-predator associations? Theoretical developments proposed by Sih (2005) presented the spatial relationships between prey and predators as a 'behavioural response race', the output of the race being the degree of association between prey and predators. If predators are 'winning' the race, a strong spatial association would be expected, while if prey are 'winning' the race, a negative spatial association would be expected. Moreover, Sih (2005) predicted that the output of the race should be driven by the existence of external constraints (termed 'spatial anchors'), the trophic level experiencing the greater constraints being the loser. In the context of the upper pelagic food web of the Bay of Biscay, the behavioural response race is a convenient theoretical model to further investigate the variability in the degree of associations between prey and predators (see also Fauchald 2009). One way to understand the observed interannual change in structure of the prey-predator community is to look for the possible spatial anchors. One constraint for predators is for example the diving performance, surface-feeding birds facing reduced prey availability compared to diving birds. Subsequently, any inter-annual variation in depth distribution of prey is likely to influence the strength of the 
prey-predator spatial association. Spatial anchors for prey may be the presence of other predators (fisheries, marine mammals, pursuit divers) able to advect preys at the surface (Camphuysen et al. 2006), or of oceanographic features having the same effect (Scott et al. 2006). Any factors making prey distribution predictable and available to the predator population, such as the existence of recurrent spawning areas (Bellier et al. 2007), may also act as a spatial anchor for prey.

Further studies should focus on the search for spatial anchors in the Bay of Biscay that can account for the inter-annual variability of prey-predator associations revealed in the present study. According to Sih (2005), these spatial anchors should be more important for prey in the years of tight prey-predator association. But these spatial anchors may change, depending on the group considered, leading to different predictions. For Delphinus delphis, Uria aalge and Sterna spp., a careful analysis of the structure and location of the spawning areas of Sardina pilchardus, Sprattus sprattus and Engraulis encrasicolus (all $10-20 \mathrm{~cm}$ in size) should be carried out, with the prediction that the prey-predator association should be stronger during the years where these fishes are breeding in predictable and/or restricted areas. By contrast, to understand prey-predator associations involving a surfacefeeder such as Morus bassanus, the focus could be put on the co-occurrence of their prey Trachurus trachurus and Scomber scombrus of moderate size $(15-25 \mathrm{~cm})$ with any factors advecting prey to the surface (marine mammals, fisheries, oceanographic features), with the prediction that the prey-predator association should be stronger during the years where prey are more likely to be advected to the surface. The predictability of these factors of concentrating and advecting prey should be scrutinised as well, with the hypothesis that the more their spatio-temporal location is predictable to the predators, the stronger the prey-predator associations should be around these locations.

\section{Design and importance of ecosystem-based monitoring programmes}

The design of ecosystem-based surveys relies on an optimal trade-off between all the sampling protocols devoted to each ecosystem component. It implies limitations on the number of people assigned to each task, the sampling area or the location of transects and stations. Such a design might be criticised because the sampling of any given component will always be less optimal than in dedicated surveys. A good example is cetacean surveys, where the 'state of the art' sampling protocol is designed to control for heterogeneities in detection rates and address biases regarding the main distance-sampling assumptions (Buckland et al. 2004). Such a protocol requires 6 observers constantly operating and only focusing on cetaceans. Other operations such as trawling, that might attract predators, are discouraged since it is important to cover as much of the survey area as possible with the available ship time. These constraints are the price to pay for estimating absolute abundances, and even with this sampling design, confidence intervals usually range from half to double the estimates (Hammond 2006). However, apart from spatial distribution and abundance, very little information can be extracted concerning the ecological processes driving the interactions between these species and their surrounding environment, because data on covariates are not simultaneously sampled. Such a constraining protocol cannot be implemented on board an ecosystem-based survey. On PELGAS cruises, only 3 places are available for the observers, meaning that only 2 can be working simultaneously while the third observer rests. Since observers collect data on seabirds, cetaceans and fishing vessels at the same time, the detection rate of cetaceans is reduced, and observations are carried out under varying weather conditions (Table 1). However, it should be taken into account that in the STATICO analysis, the use of a species profile table is a convenient way to deal with issues relating to detection probability: the relative abundance of each species in each grid cell and each year is expressed as a proportion. In this way, heterogeneities due to varying detection probability between species and between years are removed. The only remaining assumption is that detection probability for a given species in a given year does not differ between grid cells. Using larger grid cells ensures that the average observation conditions between grid cells are similar.

Biases affect not only top predator sampling, but also prey sampling. The width of the acoustic strip is narrower than the visual strip of where observations for top predators are carried out. Therefore, predators might be observed, but the fish schools on which they are preying can be missed, particularly if the schools happen to be distributed near the surface in the acoustic blind zone of the vessel (this zone is created due to the limitations of the acoustic nearfield in hullmounted transducers and can reach up to $10-15 \mathrm{~m}$; Scalabrin et al. 2009). Differential biases between small pelagic fish sampling and top predator sampling are likely to add noise to the observed patterns, therefore reducing the power with which spatial associations can be detected. Again, these biases will be even more important if the spatial scale of the analysis is reduced.

Up to now in the Bay of Biscay, existing studies on small pelagic fishes (Massé et al. 1996, Petitgas 2003) or top predators (Certain et al. 2007, 2008, Bellier et al. 
2010) did not refer explicitly to prey-predator relationships, and existing trophic web models (Sanchez \& Olaso 2004, Marquis et al. 2007) did not emphasise the coupling with apex predator populations. Information derived from the present study can be used to build complete food-web models aimed at testing scenarios of change in ecosystem structure (see Link et al. 2009 for a similar approach). Our study also illustrates the importance of simultaneously collecting data on several trophic levels during marine monitoring programmes, to obtain a broader understanding of the prey-predator community structure, leading to more focused research questions and predictions. This global analysis will facilitate more detailed, groupspecific analysis involving data at fine spatial scales, to better understand the processes controlling the spatial associations and ultimately the trophic relationships between top predators and their prey in the marine environment.

Since the results presented here only concern the spring season, our understanding of the structure of the upper pelagic food web in the Bay of Biscay - and therefore the theoretical basis for ecosystem-based management - would greatly benefit if data were also gathered in other surveys that take place at different times of the year. Indeed, although the seasonal and inter-annual variability of the top-predator community is fairly well documented in the Bay of Biscay (e.g. see Certain et al. 2007, 2008, Hemery et al. 2009), little is known about small pelagic fishes outside the spring season (but see Poulard \& Blanchard 2005); data during the winter are mainly limited to landings statistics, and spatial information is mostly limited to the scale of the ICES divisions.

Acknowledgements. We dedicate this work to the memory of Gerard Gauthier, one of the most enthusiastic observers on board the RV 'Thalassa'. We also thank all the other observers: W. Dabin, V. Magnin, V. Lahaye, M. Ballardini, S. Dixneuf, S. Baty, J. Spitz, J.-J. Boubert, H. Peltier, F. Caurant, C. Pusineri and A. Beaufils. Thanks to E. Bellier for important theoretical and statistical support, to G. J. Pierce for helpful comments and editing and to V. Ramasco for last-minute reading. Finally, we thank the editor M. Castellini and 2 anonymous referees who provided valuable criticism and helpful comments during the revision of the manuscript. M.B.S. was partially supported by EU FP7 grant FACTS (no. 244966).

\section{LITERATURE CITED}

Ainley DG, Spear LB, Tynan CT, Barth JA, Pierce SD, Ford RG, Cowles TJ (2005) Physical and biological variables affecting seabird distributions during the upwelling season of the northern California Current. Deep-Sea Res II 52:123-143

Bakun A (1996) Patterns in the ocean: ocean processes and marine population dynamics. University of California Sea Grant, San Diego, CA
Bakun A (2006) Wasp-waist populations and marine ecosystem dynamics: navigating the 'predator pit' topographies. Prog Oceanogr 68:271-288

Ballance LT, Pitman RL, Fiedler PC (2006) Oceanographic influences on seabirds and cetaceans of the eastern tropical Pacific: a review. Prog Oceanogr 69:360-390

> Bascompte J, Melian CJ, Sala E (2005) Interaction strength combinations and the overfishing of a marine food web. Proc Natl Acad Sci USA 102:5443-5447

Belisle M (1998) Foraging group size: models and a test with jaegers kleptoparasitizing terns. Ecology 79:1922-1938

- Bellier E, Planque B, Petitgas P (2007) Historical fluctuations in spawning site of anchovy (Engraulis encrasicolus) and sardine (Sardina pilchardus) in the Bay of Biscay from 1967 to 2004. Fish Oceanogr 16:1-15

> Bellier E, Certain G, Planque B, Monestiez P, Bretagnolle V (2010) Modelling habitat selection at multiple scales with multivariate geostatistics: an application to seabirds in open sea. Oikos 119:988-999

> Benhamou S (2007) How many animals really do the Lévy walk? Ecology 88:1962-1969

Buckland ST, Anderson DR, Burnham KP, Laake JL, Borchers DL, Thomas L (2004) Advanced distance sampling. Oxford University Press, Oxford

Bunce A (2001) Prey consumption of Australian gannets (Morus serrator) breeding in Port Phillip Bay, southeast Australia, and potential overlap with commercial fisheries. ICES J Mar Sci 58:904-915

Camphuysen CJ, Scott BE, Wanless S (2006) Distribution and foraging interactions of seabirds and marine mammals in the North Sea: multispecies foraging assemblages and habitat-specific feeding strategies. In: Boyd I, Wanless S, Camphuysen CJ (eds) Top predators in marine ecosystems: their role in marine monitoring and management Cambridge University Press, New York, NY, p 82-97

Certain G, Bellier E, Planque B, Bretagnolle V (2007) Characterising the temporal variability of the spatial distribution of animals: an application to seabirds at sea. Ecography 30:695-708

Certain G, Ridoux V, Van Canneyt O, Bretagnolle V (2008) Delphinid spatial distribution and abundance estimates over the shelf of the Bay of Biscay. ICES J Mar Sci 65: 656-666

Chessel D, Dufour AB, Thioulouse J (2004) The ade4 package - I: one-table methods. R News 4(1):5-9 http://cran.rproject.org/doc/Rnews/

> Clua E, Grosvalet F (2001) Mixed-species feeding aggregation of dolphins, large tunas and seabirds in the Azores. Aquat Living Resour 14:11-18

Cressie NAC (1993) Statistics for spatial data. Wiley Interscience, New York, NY

> Cury PM, Bakun A, Crawford RJM, Jarre A, Quinones RA, Shannon LJ, Verheye HM (2000) Small pelagics in upwelling systems: patterns of interaction and structural changes in 'wasp-waist' ecosystems. ICES J Mar Sci 57: 603-618

> Cury PM, Shin YJ, Planque B, Durant JM and others (2008) Ecosystem oceanography for global change in fisheries. Trends Ecol Evol 23:338-346

d'Elbée J, Hemery G (1997) Diet and foraging behaviour of the British storm petrel Hydrobates pelagicus in the Bay of Biscay during summer. Ardea 85:1-10

> Davoren GK, Montevecchi WA, Anderson JT (2003) Distributional patterns of a marine bird and its prey: habitat selection based on prey and conspecific behaviour. Mar Ecol Prog Ser 256:229-242

deYoung B, Barange M, Beaugrand G, Harris R, Perry RI, 
Scheffer M, Werner F (2008) Regime shifts in marine ecosystems: detection, prediction and management. Trends Ecol Evol 23:402-409

> Dolédec S, Chessel D, Gimaret-Carpentier C (2000) Niche separation in community analysis: a new method. Ecology 81:2914-2927

$>$ Dray S, Chessel D, Thioulouse J (2003) Co-inertia analysis and the linking of ecological data tables. Ecology 84: 3078-3089

Dray S, Dufour AB, Chessel D (2007) The ade4 package - II: two-table and K-table methods. R News 7(2):47-52 http://cran.r-project.org/doc/Rnews/

Ellis HI, Gabrielsen GW (2001) Energetics of free-ranging seabirds. In: Schreiber EA, Burger J (eds) Biology of marine birds. CRC Press, Boca Raton, FL, p 359-407

Espinoza P, Bertrand A, van der Lingen CD, Garrido G, Rojas de Mendiola B (2009) Diet of sardine (Sardinops sagax) in the northern Humboldt Current system and comparison with the diets of clupeoids in this and other eastern boundary upwelling systems. Prog Oceanogr 83:242-250

Fauchald P (1999) Foraging in a hierarchical patch system. Am Nat 153:603-613

Fauchald P (2009) Spatial interaction between seabirds and prey: review and synthesis. Mar Ecol Prog Ser 391: 139-151

Fauchald P, Erikstad KE, Skarsfjord H (2000) Scaledependent prey-predator interactions: the hierarchical spatial distribution of seabirds and prey. Ecology 81: 773-783

Furness RW, Hamer K (2003) Skuas and Jaegers. In: Perrins CM (ed) Firefly encyclopedia of birds. Oxford University Press, New York, NY, p 270-273

Garthe S, Hüppop O (1998) Foraging success, kleptoparasitism and feeding techniques in scavenging seabirds: does crime pay? Helgol Meeresunters 52:187-196

Gremillet D, Pichegru L, Kuntz G, Woakes AG, Wilkinson S, Crawford RJM, Ryan PG (2008) A junk-food hypothesis for gannets feeding on fishery waste. Proc Biol Sci 275: $1149-1156$

Hamer KC, Lewis S, Wanless S, Phillips RA and others (2006) Use of gannets to monitor prey availability in the northeast Atlantic Ocean: colony size, diet and foraging behaviour. In: Boyd IL, Wanless S, Camphuysen CJ (eds) Top predators in marine ecosystems: their role in monitoring and management. Cambridge University Press, New York, NY, p 236-248

Hammond P (ed) (2006) Small cetaceans in the European Atlantic and North Sea (SCANS-II). LIFE04NAT/GB/ 000245 final report. Sea Mammal Research Unit, St. Andrews, Scotland

Haugland EK, Misund OA (2004) Evidence for a clustered spatial distribution of clupeid fish schools in the Norwegian Sea and off the coast of southwest Africa. ICES J Mar Sci 61:1088-1092

Hemery G, D'Amico F, Castège I, Dupont B, d'Elbée J, Lalanne Y, Mouchès C (2009) Detecting the impact of oceano-climatic changes on marine ecosystems using a multivariate index: the case of the Bay of Biscay (North Atlantic-European Ocean). Glob Change Biol 2008:27-38

Hunt GL, McKinnel S (2006) Interplay between top-down, bottom-up, and wasp-waist control in marine ecosystems. Prog Oceanogr 68:115-124

Hunt GL, Drew GS, Jahncke J, Piatt JF (2005) Prey consumption and energy transfer by marine birds in the Gulf of Alaska. Deep-Sea Res II 52:781-797

ICES (2010) Report of the Working Group on Anchovy and Sardine (WGANSA), 24-28 June 2010, Lisbon, Portugal.
ICES CM 2010/ACOM:16. ICES, Copenhagen

Kenney RD, Scott GP, Thompson TJ, Winn HE (1997) Estimate of prey consumption and trophic impacts of cetaceans in the USA Northeast Continental Shelf ecosystem. J Northwest Atl Fish Sci 22:155-171

Koutsikopoulos C, Le Cann B (1996) Physical processes and hydrological structures related to the Bay of Biscay anchovy. Sci Mar 60:9-19

> Lance MM, Thompson CW (2005) Overlap in diets and foraging of common murres (Uria aalge) and rhinoceros auklets (Cerorhinca monocerata) after the breeding season. Auk 122:887-901

Léauté JP (1998) Les flotilles de pêche de l'Union Européenne dans le golfe de Gascogne vues du ciel. Oceanol Acta 21:371-381

> Lewison RL, Crowder LB, Read AJ, Freeman SA (2004) Understanding impacts of fisheries bycatch on marine megafauna. Trends Ecol Evol 19:598-604

Limmer B, Becker PH (2009) Improvement in chick provisioning with parental experience in a seabird. Anim Behav 77:1095-1101

> Link J, Col L, Guida V, Dow D and others (2009) Response of balanced network models to large-scale perturbations: implications for evaluating the role of small pelagics in the Gulf of Maine. Ecol Model 220:351-369

Lorentsen SH, Anker-Nilssen T (1999) Diet of common murres wintering in the northern Skagerrak during 19881990: variation with sex, age and season. Colon Waterbirds 22:80-89

> Marquis E, Niquil N, Delmas D, Hartmann HJ and others (2007) Planktonic food web dynamics related to phytoplankton bloom development on the continental shelf of the Bay of Biscay, French coast. Estuar Coast Shelf Sci 73:223-235

Massé J (1988) Utilisation de l'écho-intégration en recherche halieutique. DRV Ifremer, Nantes

Massé J, Koutsikopoulos C, Patty W (1996) The structure and spatial distribution of pelagic fish schools in multispecies clusters: an acoustic study. ICES J Mar Sci 53:155-160

Meynier L, Pusineri C, Spitz J, Santos MB, Pierce GJ, Ridoux V (2008) Intraspecific dietary variation in the shortbeaked common dolphin Delphinus delphis in the Bay of Biscay: importance of fat fish. Mar Ecol Prog Ser 354: $277-287$

> Myers RA, Baum JK, Shepherd TD, Powers SP, Peterson CH (2007) Cascading effects of the loss of apex predatory sharks from a coastal ocean. Science 315:1846-1850

- Palomera I, Olivar MP, Salat J, Sabatés A, Coll M, Garcia A, Morales-Nin B (2007) Small pelagic fish in the NW Mediterranean Sea: an ecological review. Prog Oceanogr 74:377-396

> Pauly D, Trites AW, Capuli E, Christensen V (1998) Diet composition and trophic levels of marine mammals. ICES J Mar Sci 55:467-481

Pebesma EJ, Wesseling CG (1998) Gstat: a program for geostatistical modelling, prediction and simulation. Comput Geosci 24:17-31

Petitgas P (2003) A method for the identification and characterization of clusters of schools along the transect lines of fisheries-acoustic surveys. ICES J Mar Sci 60:872-884

> Petitgas P, Goarant A, Massé J, Bourriau P (2009) Combining acoustic and CUFES data for the quality control of fishstock survey estimates. ICES J Mar Sci 66:1384-1390

> Pikitch EK, Santora C, Babcock EA, Bakun A and others (2004) Ecosystem-based fishery management. Science 305:346-347

Pinaud D, Weimerskirch H (2005) Scale-dependent habitat 
use in a long-ranging central place predator. J Anim Ecol $74: 852-853$

Planque B, Lazure P, Jégou AM (2004) Detecting hydrological landscapes over the Bay of Biscay continental shelf in spring. Clim Res 28:41-52

Planque B, Bellier E, Lazure P (2007) Modelling potential spawning habitat of sardine (Sardina pilchardus) and anchovy (Engraulis encrasicolus) in the Bay of Biscay. Fish Oceanogr 16:16-30

Poulard JC, Blanchard F (2005) The impact of climate change on the fish community structure of the eastern continental shelf of the Bay of Biscay. ICES J Mar Sci 62:1436-1443

Puillat I, Lazure P, Jégou AM, Lampert L, Miller PI (2004) Hydrographical variability on the French continental shelf in the Bay of Biscay, during the 1990s. Cont Shelf Res 24:1143-1163

Pusineri C, Magnin V, Meynier L, Spitz J, Hassani S, Ridoux $\mathrm{V}$ (2007) Food and feeding ecology of the common dolphin (Delphinus delphis) in the oceanic Northeast Atlantic and comparison with its diet in neritic areas. Mar Mamm Sci 23:30-47

R Development Core Team (2008) R: a language and environment for statistical computing, v. 1.8.1. R Foundation for Statistical Computing, Vienna

Reid DG, Turrell WR, Walsh M, Corten A (1997) Cross-shelf processes north of Scotland in relation to the southerly migration of Western mackerel. ICES J Mar Sci 54: $168-178$

Ridoux V (1987) Feeding association between seabirds and killer whales, Orcinus orca, around subantarctic Crozet Islands. Can J Zool 65:2113-2115

Russell RW, Hunt GL Jr, Coyle OK, Cooney RT (1992) Foraging in a fractal environment: spatial patterns in a marine prey-predator system. Landscape Ecol 7:195-209

Sanchez F, Olaso I (2004) Effects of fisheries on the Cantabrian Sea shelf ecosystem. Ecol Model 172:151-174

Scalabrin C, María C, Boucher J (2009) How much fish is hidden in the surface and bottom acoustic blind zones? ICES J Mar Sci 66:1355-1363

Scott BE, Sharples J, Wanless S, Ross ON, Frederiksen M, Daunt F (2006) The use of biologically meaningful oceanographic indices to separate the effects of climate and fisheries on seabird breeding success. In: Boyd I, Wanless $\mathrm{S}$, Camphuysen CJ (eds) Top predators in marine ecosystems: their role in monitoring and management. Cambridge University Press, New York, NY, p 46-62

Sih A (2005) Prey-predator space use as an emergent outcome of a behavioural response race. In: Barbosa $\mathrm{P}$, Castellanos I (eds) Ecology of prey-predator interactions. Oxford University Press, New York, NY, p 240-301

Silverman ED, Veit RR, Nevitt GA (2004) Nearest neighbours as foraging cues: information transfer in a patchy environ-

Editorial responsibility: Michael Castellini,

Fairbanks, Alaska, USA ment. Mar Ecol Prog Ser 277:25-35

Simmonds J, MacLennan D (2005) Fisheries acoustics: theory and practice, 2nd edn. Blackwell Science, Oxford

Sissenwine MP, Overholtz WJ, Clark SH (1984) In search of density dependence. In: Metleff BR, Rosenberg DH (eds) Proceedings of the workshop on biological interactions among marine mammals and commercial fisheries in the southeastern Bering Sea. Alaska Sea Grant report 84-1. Alaska Grant College Program. University of Alaska, Fairbanks, AK, p 119-137

Snow DW, Perrins CM (1998) The birds of the western Palearctic. Oxford University Press, New York, NY, p 773-782

Spitz J, Rousseau Y, Ridoux V (2006) Diet overlap between harbour porpoise and bottlenose dolphin: an argument in favour of interference competition for food? Estuar Coast Shelf Sci 70:259-270

Tasker ML, Jones PH, Dixon TJ, Blake BF (1984) Counting seabirds at sea from ships: a review of methods employed and a suggestion for a standardized approach. Auk 101: $567-577$

Thioulouse J, Chessel D (1987) Multi-table analysis in factorial ecology. Acta Oecol 8:463-480

Thioulouse J, Simier M, Chessel D (2004) Simultaneous analysis of a sequence of paired ecological tables. Ecology 85:272-283

> Uriarte A, Lucio P (2001) Migration of adult mackerel along the Atlantic Europoean shelf edge from a tagging experiment in the south of the Bay of Biscay in 1994. Fish Res 50:129-139

Valeiras X (2003) Attendance of scavenging seabirds at trawler discards off Galicia, Spain. Sci Mar 67:77-82

Viswanathan GM, Afanasyev V, Buldyrev SB, Murphy EJ, Prince PA, Stanley HE (1996) Levy flight search patterns of wandering albatrosses. Nature 381:413-415

Votier SC, Furness RW, Bearhop S, Crane JE and others (2004) Change in fisheries discard rates and seabirds communities. Nature 427:727-730

> Votier SC, Bearhop S, Fyfe R, Furness RW (2008) Temporal and spatial variation in the diet of a marine top predator: links with commercial fisheries. Mar Ecol Prog Ser 367: 223-232

- Wanless S, Frederiksen M, Daunt F, Scott BE, Harris MP (2007) Black-legged kittiwakes as indicators of environmental change in the North Sea: evidence from long term studies. Prog Oceanogr 72:30-38

Weimerskirch H (2007) Are seabirds foraging for unpredictable resources? Deep-Sea Res II 54:211-223

Weimerskirch H, Le Corre M, Jaquemet S, Marsac F (2005) Foraging strategy of a tropical seabird, the red footed booby, in a dynamic marine environment. Mar Ecol Prog Ser 288:251-261

Submitted: June 18, 2010; Accepted: November 14, 2010 Proofs received from author(s): January 19, 2011 